\title{
Gerakan Ekonomi Umat Melalui Program Baitul Maal Wat Tamwil (BMT)
}

\author{
Oleh Amir Mu'allim
}

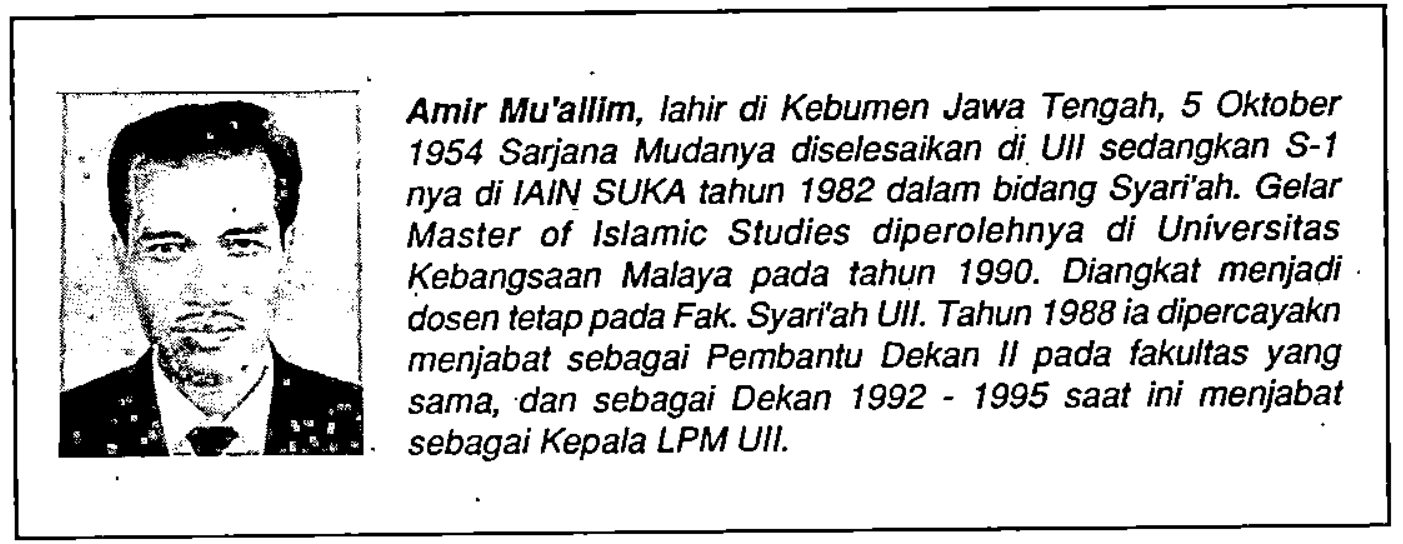

\section{Pendahuluan}

Pola hidup manusia berkaitan erat dengan kondisi dan situasi yang melingkupinya. Persoalan makro yang dihadapi manusia adalah bagaimana dapat memenuhi hajat hidupnya terutama .yang menyangkut kebutuhan sandang, pangan dan papan. Pemikiran semacam ini lebih banyak ditekankan kepada individunya (akunya) artinya bagaimana "saya" dapat berpakaian dengan baik, makan yang enak dan memiliki tempat tinggal yang nyaman. Jarang sekali orang yang berfikir tentang bagaimana tetangga kita dapat hidup layak, kecukupan sandang, pangan dan papan bahkan terhadap keluarganya sendiripun banyak terjadi demikian.

Prinsip keseimbangan seperti yang dicanangkan dalam agama Islam dan juga oleh berbagai pihak termasuk pemerintah harus dimiliki oleh setiap orang dan sudah barang tentu disesuaikan dengan kadar kemampuan masing-masing orang harus memiliki kepedulian dengan orang lain. Sabda Nabi Muhammad saw yang diriwayatkan oleh Buchori dan Muslim menyebutkan yang maksudnya bahwa tiap-tiap muslim haruslah bersodakoh. Sahabat bertanya : Bagaimana kalau dia tidak mampu ya Rasulullah ? Jawab Nabi : Dia harus berusaha dengan kedua tangan (tenaga)nya hingga berhasil untuk dirinya dan untuk bersedekah. Sahabat bertanya.: Bagaimana kalau dia tidak mampu (berhasil) ? nabi menjawab : Dia melakukan sesuatu perbuatan baik atau menahan dirinya dari perbuatan mungkar (kejahatan) itupun merupakan shodaqoh baginya.
Sabda Nabi tersebut memberikan sinyal kepada kita tentang keharusan untuk dapat berbuat sesuatu kepada orang lain baik secara material maupun aspek immateial, yang dalam kajian ini lebih dititik beratkan kepada material dan lebih spesifik lagi tentang ekonomi umat dalam tatanan syari'at Islam, yang berkaitan dengan program Baitul Maal wat Tamwil.

\section{Sumber Perekonomian}

Salah satu tugas manusia dimuka bumi ini adalah memakmurkan alam disamping beribadah kepada Allah SWT. Hal ini disebutkan dalam al Qur'an yang maksudnya Dialah Allah yạng menjadikan segala yang ada dibumi untuk kamu dan Dia berkehendak (menciptakan ) langit, lalu dijadikannya tujuh langit. Dia maha mengetahui segala sesuatu (al Baqoroh: 29). Dalam surat lain disebutkan bahwa : Katakanlah : Perhatikanlah apa yang ada dilangit dandi bumi. Tidaklah bermanfaat tanda kekuasaan Allah dan Rasul-Rasul yang memberi peringatan bagi orang-orang yang menunggu bersama kamu.(Yunus : 101)

Sumber kekayaan alam harus digali dengan semangat seolah-olah kita akan hidup selamanya dan diusahakan agar anak keturunan kita tidak terlantar (an Nisa' : 9), akan tetapi usaha kita harus diimbangi dengan pemahaman kewajiban beribadah yang seolah-olah kita akan mati besok. Oleh karena itu prinsip halalan thoyyiban dalam mencari sumber kekayaan menjadi landasan yang utama.

Agar nilai manfaat harta tidak sekedar mandeg 
untuk diri sendiri maka prinsip kebersamaan dalam mencari sumber kekayaan merupakan hal yang sangat penting, kelompok-kelompok yang mengatas namakan dirinya penghimpun dana seperti BAZIS, Panitia zakat dan lain sebagainya merupakan bukti kepedulian mereka tentang perlunya kebersamaan dalam mencari sumber perekonomian. Namun kalau dilihat dari sisi pendistribusiannya lebih banyak menekankan kepada transfer dana yang sifatnya masih berimplikasi kepentingan sepihak belum bersifat timbal balik.

Badan-badan yang mengatas namakan dirinya bank juga dapat dikatakan masih berorientasi sepihak karena tidak ada bagian yang betul-betul lepas untuk kepentingan pihak lain apalagi kalau sudah berbicara masalah bunga maka yang tergambar adalah antara haram dan halal, walaupun sekarang sudah ada Bank Mu'amalat indonesia yang menghindari istilah bunga namun masih menjadi trauma masyarakat yang mengkaitkan antara Bank dengan bunga.

Lembaga yang menamakan dirinya BAZIS (Badan Amil Zakat Infaq dan Shodaqoh) kiranya bclum mampu secara optimal mengumpulkan kckayaan dari para "aghniya" (orang-orang kaya), karena meskipun dari sisi keberadaannya berfungsi secara permanen tetapi operasionalnya lebih banyak bersifat musiman/tcmporcr. Persepsinya masyarakat yang masih klasik bahwa mengelụarkan zakat pada bulan Ramadlon masih sulit untuk dicegah, padahal zakat sangat berkaitan erat dengan perhitungan matematis dan hukum persyaratan adanya nishab (batas minimal harta untuk dikeluarkan zakatnya) dengan kaul (harta yang terkumpul sudah mencapai waktu stu tahun) harus menjadi pedoman dalam pengaturan zakat. Hal yang sangat membuat kita prihatin apa yang dikatakan Masdar Farid pada wawancara tayangan TVRI tanggal 26 Maret 1996 yang mengatakan bahwa bangkrutnya pengelolaan zakat menjadikan fungsi zakat bclum sesuai dengan status zakat dalam mengentaskan kemiskinan

Mengkaji dari kenyataan yang ada maka telah dicanangkan lembaga yang menamakan Bitul maal Wat Tamwil (BMT) sebagai lembaga keungan non bank yang dijalankan dengan dasar landasan konsep Syari'ah (Islam) dengan meniadakan bunga sebagai cara pengambilan keuntungan.

Oleh karena itu dengan kejelasan status lembaga (BMT) tersebut diperlukan pengertian dan dukungan kaum Muslim untuk memperkuat keberadaannya yang sekaligus sebagai umber perekonomian yang halal dan dapat dirasakan oleh semua pihak terutama kalangan menengah kebawah.

\section{Sistem Pengelolaan}

Untuk menghindari kemacetan dan kebangkrutan dalam pengelolaan keungan serta aspek-aspek yang meragukan masyarakat maka, perlu ditopang dengan manajemen yang memadai. mka prinsip yang ditawarkan dalam mekanisme putaran uang dalam Islam ada sejumlah nama yang dapat mewadahi mekanisme tersebut yaitu :

\section{Mudhorobah}

Mudhorobah adalah perjanjian antara pemilik modal dengan pengusaha, dimana pemilik modal sepakat membiayai sepenuhnya suatu proyek pemiagaan atau industri dan pengusaha sepakat mengusahakan secara berkongsi atau dalam bentuk persekutuan (partneship) dengan pembagian laba yang ditetapkan menurut perbandingan tcrtentu. Pemilik modal tidak ikut dalam pengelolaan proyck, tclapi dapat melakukan pengawasin.

2. Musyarokah.

Musyarokah adalah perjanjian persckutuan (partnership) anatara dua pemilik modal alau lebih untuk menjalankan suatu proyck perniagaan atau industri dimana mercka bersama-sama scpakat mengembangkan modal dan membagi kcuntungan bersama. Keuntungan dibagi kepada para sckutu menurut perbandingan yang tclah disepakati lcbih dahulu, sedangkan kalau terjadi kcrugian harus dipikul olch para anggota sekutu menurut perbandingan modal masing-masing.

\section{Murobahah}

Murobahah adalah perjanjian jual beli antara pemilik barang dengan pembeli. Penjual mentetapkan hargajual dengan menambah keuntungan tertentu dalam penentuan harga jual perlu ada kescpakatan kedua belah pihak.

\section{Ba'i Bitsaman Ajil}

Perjanjian jual beli antara pemilik barang dengan pembcli dengan syarat pembayarannya ditangguhkan atau diangsur.

\section{Qardlul Hasan}

Qardlul Hasan atau pinjaman kcbajikan adalah perjanjian antara pihak yang memberi pinjaman dengan yang meminjam yang berisi kesepakatan bahwa yangmemberi pinjaman akan menyerahkan scjumlah uang tertentu kepada peminjam yang akan dikembalikan pada saat tertentu sebesar jumlah yang pada waktu diterima.Dasar yangmelandasi peminjaman kebajikan adalah membantu golongan/ orang yang miskin dan lemah.

Implementasi dari beberapa mekanisme tersebut harus didukung subyek hukum yang terkait yang dilandasi dengan :

a. Usaha untuk mencari pemasukan dari sumber yang halal dan digunakan untuk keperluan yang halal. Prinsip ini menjadi landasan utama karena istilah 
halal dan haram adalah sesuatu yang sangat peka walaupun dalam prakteknya beberapa hal masih ada yang masih menjadi perselisihan. Oleh karena itu dalam menonjolkan prinsip ini menggunakan acuan firman Allah yang maksudnya "jangan sekali-kali kamu mencampuradukan antara yang hak dengan yang bathil" (al Baqoroh : 42)

b. Saling percaya mempercayai

Timbulnya kerenggangan dalam berkongsi/kerja sama antara lain adanya ketidak percayaan antara satu sama lain, sehingga akibat banyaknya prasangka bunuk menjadikan ide bersih yang muncul pada awal mula menjadi tidak nyaman.

c. Jujur

Ada sebuah sabda Nabi yang menyebutkan bahwa dusta dalamm jual beli itu dapat menambah keuntungan materi tetapi dapat menguangi barokah

Sabda nabi tersebut sesungguhnya mangandung pengertian tentang pentingnya berbuat jujur dalam mengadakan transaksi. Apabila mengkaji tentang nilai tambah justru istilah barokahnya mempunyai nilai lebih dari sekedar keuntungan materi yang dipcrolch karena dusta, karena pengertian barokah adalah tambahnya nilai kebaikan. Apabila kebaikan itu datangnya dari Allah sulit untuk dihitung secara matematis.

\section{d. Semangat yang tinggi}

Pesan Al Qur'an yang tercantum dalam surat Alam Nasyroh yang menyebutkan bahwa "mika apabila kamu telah selesai (dari sesuatu urusan) kerjakanlah dengan sungguh-sungguh (urusan) yang lain" (Alam Nasyroh : 7), menunjukkan bahwa Islam sangat menekankan tentang kerja keras dan anli kemandegan. Sifat kompetitif yang dalam al ur'an disebut "Fastabiqul Khairat" adalah pesan yang memacu dan memicu semangat dalam berkarya dan ini punya maka ganda baik untuk kepentingan dunia maupun untuk kepentingan akhirt.

\section{e. Keadilan}

Dalam operasionalisasi kerja sama bidang bisnis banyak yang dikerjakan olch satu pihak artinya pihak pertama memberikan modalnya dan pihak kedua membelanjakan modalnya. Bagi yang membelanjakan modalnya dapat secara leluasa mengoperasionalkan modal dan dapat mengupayakan untuk mencari modal yang sebanyak-banyaknya. Dalam pembagian hasil dimungkinkan 'satu" sama lain mengklaim untuk mendapat hak yang lebih banyak. Oleh karena itu jiwa keadilan tidak sekedar dilihat dari unsur materi tetapi dapat dilihat dari berbagai segi dan yang lebih penting lagi adalah prinsip adil dalam kebersamaan.

Untuk mewadahi jaringan sistem tersebut lembaga
Baitul Mal Wattamwil (BMT) menawarkan peluang bagi masyarakat untuk mendukung kemjuan ekonomi Islam yang secara operasional mempunyai dwi fungsi yaitu :

Baitul Mal, berfungsi menerima dan menyalurkan zakat infak dan shodaqoh.

Baitul Tamwil berfungsi mengembangkan usahausaha produktif dan investasi dalam meningkatkan kualitas usaha ekonomi pengusaha kecil (bawah) dengan cara antara lain mendoròng kegiatan menabung pembiayaan usaha.

Dilihat dari segi nama yang meniadakan istilah bank maka BMT sangat tepat untuk dikembangkan dalam upaya untuk meluruskan dan memperkuat citra lembaga ekonomi Islam. Oleh karena itu diperlukan adanya gayung bersambut untuk menumbuh kembangkan BMT ditengah-tengah masyarakat.

\section{Pendistribusian}

Berdasarkan perhitungan angka bahwa sebagian besar rakyat Indonesia adalah beragama Islam. Maka kalau dialas kertas angka kemiskinan di Indonesia masih menonjol maka dapat juga dipastikan bahwa mayoritas yang miskin juga orang-orang Islam. Dikemukakan bahwa teori distribusi hendaknya dapat mengatasi masalah distribusi pendapatan nasional diantara berbagai kclas rakyat. Terutama ia harus mampu menjelaskan fenomena, bchwa sebagian kecil orang kaya raya, scdangkan bagian terbesarnya adalah orang miskin (Abdul Manarı, 1993 : 113).

Kcberadaan 'lembaga-lembaga" yang mengatasnamakan dirinya sebagai lembaga bonafide bclum banyak menyentuh kalangan bawah. Hal ini dikarcnakan adanya kesenjangan diantara kedua belah pihak. Bagi kalangan atas (lembaga-lembaga bonafide) lcbih banyak memandang ekonomi dari sisi untung rugi dan kurang memandang faktor sosial. Sebaliknya kalangan bawah ada rasa kekhawatiran tentang kemungkinan tidak bisanya berkomunikasi dengan kalangan atas karena faktor birokrasi disamping berbagai kendala sosial yang menjadikan rasa enggan untuk menjadi partner kerja/bisnis.

Oleh karena itu tepat kiranya yang dikatakan Abu Surai bahwa hampir tak ada orang yang berselisih untuk mengatakan bahwa masyarakat yang para individunya berlaku egois, tidak saling membantu, golongan kayanya kepentingannya berlawanan dengan golongan papa, tentu masyarakat semacam ini tak akan bisa berdiri pada pondasi yang kuat (Abu Surai, $1991: 1$ ).

Prinsip kelembagaan perekonomian Islam dicanangkan untuk mengisolasi kesenjangan tersebut dan menekankan pada hubungan kemesraan antara si kaya dengan si miskin atau yang kuat dengan yang 
lemah. Maka seperti halnya BMT didirikan dalam rangka membantu ekonomi lemah agar nantinya menjadi manusia yang tidak selalu dalam ketergantungan dan bebas dari kefakiran, karena kefakiran dapat menjadikan orang kafir.

\section{Mengantisipasi Persaingan}

Prospek perekonomian Islam seperti halnya yang ada sekarang ini perlu dukungan yang serius dikalangan umat Islam. Kurang berkembangnya lembaga perekonomian Islam antara lain dapat dilihat dari :

1. Kurangnya perhatian dikalangan atas (orang-orang kaya) untuk menyatu dengan lembaga-lembaga perekonomian Islam. Ada kemungkinan faktor yang melatar belakangi adalah warisan persepsi yang menganggap bahwa lembaga-lembaga perekonomian Islam kurang dapat dihandalkan dalam sistem pengelolaannya, dan lebih ironis lagi yang mengatakan bahwa berkongsi dengan lembagalembaga perekonomian Islam harus ada persiapan untuk ikhlas melepaskannya.

2. Pengendalian manajemen yang kurang kompetitif. Penampilan yang baik dan meyakinkan merupakan point sendiri dalam persaingan suatu usaha. Pada hakekatnya prinsip ini tidak bertentangan dengan Islam karena Allah adalah Zat yang maha indah dan senang kepada keindahan, oleh karena itu suatu usaha yang mapan harus disertai dengan prototipe yang meyakinkan. Untuk mengantisipasi berbagai persepsi tersebut perlu usaha-usaha yang dapat mengangkat dan memadukan kesejajaran lembaga perekonomian Islam di tengah-tengah masyarakat.

Suatu hal yang kurang berani dilakukan oleh pengelola lembaga perekonomian Islam adalah menimba pengalaman. Seolah-olah kalau mengadopsi pengalaman dari lembaga-lembaga non Islam adalah haram, padahal Nabi sendiri telah memberi kebebasan dengan sabdanya "Carilah ilmu walau ke negeri Cina". Oleh karena itu tepat kiranya apa yang dikatakan Musa Asy-ari bahwa tidak ada faktor tunggal dalam kemiskinan. Karena itu penanggulangannya juga tidak dapat dilakukan hanya dengan cara pendekatan yang tunggal, dan diperlukan adanya pendekatan yang melibatkan berbagai disiplin ilmu pengetahuan dan dari berbagai aspek kehidupan (Musa Asy'ari, makalah 9 April 1994).

Disamping itu untuk merangsang daya tarik dari para penyandang dana dan pengguna dana adalah pengertian bahwa memperkuat ekonomi Islam mempunyai nilai ganda yaitu keuntungan materi dan mendapatkan pahala dan pahitnya seandainya terjadi ketidakstabilan dan terjadi kebangkrutan dengan tidak disengaja maka termasuk jihad fisabilillah. Sebagaimana disebutkan dalam Al-Qur'an bahwa Allah melebihkan

orang-orang yang berjihad dengan harta dan jiwanya atas orang-orang yang duduk satu derajat (An-Nisa' : 95), dikuatkan dengan Sabda Nabi yang mengatakan bahwa barang siapa yang mati karena membela hartanya maka dia termasuk mati syahid (H.R. Arba'ah dan disyahkan oleh Tirmidzi).

Oleh karena itu. untuk mendukung kekuatan ekonomi Islam harus dapat menanamkan rasa kepercayaan bahwa membantu ekonomi Islam berarti membantu dirinya sendiri dan mematikan ekonomi Islam berarti mematikan dirinya sendiri.

Sebagai ilustrasi berikut contoh tentang operasionalisasi lembaga ekonomi Islam dalam wadah Baitul Maal Wat tamwil yang akan dan telah berjalan yang ditawarkan dalam bentuk proposal sebagai berikut :

1. Jenis Usaha

2. Jumlah pinjaman

3. Jangka waktu

4. Jumlah penjualan

5. Biaya operasional
a. Tenaga kerja
b. Transportasi
c. Rupa-rupa

6. Laba

7. Jenis pembiayaan

8. Prosentase keuntungan
a. Anggota
b. BMT
:50\% x Rp. 100.000,-= Rp. 50.000 ,-
:50\% x Rp. $100.000,-=$ Rp. 50.000 ,-

: Catering dan pemondokan

:Rp. 1.000.000,- (satu juta rupiah)

$: 1$ (satu) bulan

:Rp. 1.500.000,- (satu juta lima ratus rupiah)

:Rp. 200.000,-

:Rp. 50.000 ,-

:Rp. 1.150.000,-

:Rp. 100.000,-

: Mudhorobah
Dari kalkulasi akhir hitungan tersebut nampak bahwa dari modal 1 juta rupiah dalam jangka 1 bulan mendapat keuntungan Rp. 100.000,- dan hal ini apabila dibandingkan dengan sistem perbankan yang memberikan bunga $15 \% 1$ tahun maka sangat jauh perbedaannya.

\section{Penutup}

Sudah waktunya kita Umat Islam untuk menggalang persatuan membentuk kekuatan dalam bidang perekonomian sesuai dengan Syari'at Islam.

BMT sebagai lembaga yang bergerak. dalam bidang perekonomian dengan prinsip Islam sangat diperlukan keterlibatan semua pihak secara timbal balik agar dominasi ekonomi dapat diambil alih oleh masyarakat Islam. Mudah-mudahan konsep ini mendapat perhatian kita semua dan ada manfaatnya. 


\section{Daftar Pustaka}

Abdulhadi, Abu Sura'i, Bunga Bank Dalam Persoalan dan Bahayanya Terhadap Masyarakat, Yayasan Masjid Mananul Islam bangil dan Pustaka LSI Yogyakarta, 1991.

Abdul Mannan Muhammad, Teori dan Praksek Ekonomi Islam, PT. Dana Bhakti Wakaf, Yogyakarta, 1993. As Shan any, Subulus Salam, Dahlan, Bandung, tt.
Departemen Agama RI, Al-Qur'an dan Terjemahannya, CV Kathoda, Jakarta, 1990.

Musa Asy'ari, Ekonomi dan Kemiskinan Tinjauan Agama (makalah diskusi UNISIA) 9 April 1994. Sukamto, Bank Muamalat Indonesia Problema Pengendalian dan Prospeknya (naskah pidato Dies UII ke 48) 3 Februari 1992.

Tcam Pcnerangan BAZIS, Pedoman Pengelolaan Zakat dan Infak/Shodaqoh, Pemerintah Daerah Khusus Ibukota, Jakarta, 1980. 